\title{
Apoptosis and Efferocytosis in Inflammatory Diseases
}

\author{
Chandra Agung Purnama ${ }^{1,2}$, Anna Meiliana ${ }^{1,2,3}$, Melisa Intan Barliana ${ }^{4,5}$, \\ Keri Lestari Dandan ${ }^{1,5}$, Andi Wijaya ${ }^{2,3}$ \\ 'Department of Pharmacology and Clinical Pharmacy, Faculty of Pharmacy, Universitas Padjadjaran, Jl. Raya Bandung-Sumedang Km 21, \\ Jatinangor 45363, Indonesia \\ ${ }^{2}$ Prodia Clinical Laboratory, Jl. Supratman No 43, Bandung 40114, Indonesia \\ ${ }^{3}$ Prodia Education and Research Institute, Jl. Kramat Raya No. 150, Jakarta, 10430, Indonesia \\ ${ }^{4}$ Department of Biological Pharmacy, Faculty of Pharmacy, Universitas Padjadjaran, Jl. Raya Bandung-Sumedang Km 21, Jatinangor 45363, Indonesia \\ ${ }^{5}$ Center of Excellence in Higher Education for Pharmaceutical Care Innovation, Universitas Padjadjaran, Jl. Raya Bandung-Sumedang Km 21, \\ Jatinangor 45363, Indonesia \\ *Corresponding author. E-mail: anna.meiliana@prodia.co.id
}

Received date: May 5, 2021; Revised date: Aug 28, 2021; Accepted date: Sep 8, 2021

\section{Abstract}

B ACKGROUND: Millions of cells in multicellular organisms regenerate every day to replace aged and died cells. Effective cell clearance (efferocytosis) is critical for tissue homeostasis, as the human body recycles its cellular components. We summarize what is known about the mechanisms of efferocytosis and how it impacts the physiology of the organism, effects on inflammation and the adaptive immune response, as well as the consequences of defects in this critical homeostatic mechanism in this review.

CONTENT: Cell death is the process by which the human body replaces aged or damaged cells with new ones. It can be triggered by genetically encoded machinery or regulated cell death, or by specific pharmacologic or genetic interventions, resulting in accidental cell death. Dying cells release signals that entice phagocytes to engulf them in a process known as efferocytosis. Efferocytosis is a multistep process involving the release of "find me" and "eat me" signals and destruction of death cells by phagocytes. Different types of cell death including apoptosis and necroptosis can express pro- or anti-inflammatory signals via macrophage activity modulation.

SUMMARY: Failed or ineffective efferocytosis can result in disruption of tissue homeostasis, which can contribute to the development of chronic inflammatory diseases such as atherosclerosis, obesity, diabetes, and heart failure. Therefore, any therapeutic strategy that enhances efferocytosis will have a beneficial effect on the treatment of these metabolic disorders.

KEYWORDS: apoptosis, necroptosis, phagocytosis, efferocytosis, macrophage.

Indones Biomed J. 2021; 13(3): 242-55

\section{Introduction}

Every day, human body regenerates by replacing about $0.4 \%$ of old or demaged cells out of the estimated 37.2 trillion cells in the human body.(1) Some tissues have a higher turnover than other tissues and therefore need a higher clearance rate of apoptotic cells (ACs) through a process termed as 'efferocytosis'. When the clearance of death cells is efficient and high in capacity, the ACs are scarce, and the homeostasis is well-balanced, as well as the restoration of homeostasis related disease. $(2,3)$ Efferocytosis is mechanisms different from those of classic phagocytosis, either in term of morphologically or mechanistically. In phagocytosis, the process of clearance requires a set of phagocyte expression signals and receptors, reorganize the phagocyte cytoskeleton to engulf cell-bound $\mathrm{ACs}$ and induce phagosome-lysosome fusion to degrade AC cargo. $(4,5)$ When the number of ACs are much higher than available classical phagocytes, such as those after acute 
inflammatory responses, phagocytes have to able to ingest ACs in a short time, known as continual efferocytosis. In this setting, macrophages reduce inflammation to mediate tissue repair and resolution. $(3,4)$ However, in a defective efferocytosis, such process is failed wich can often lead the disruption of tissue.

Phagocytes undergoing continuous AC uptake face a number of challenges.(5) We summarize what is known about the mechanisms of efferocytosis and how it impacts the physiology of the organism, effects on inflammation and the adaptive immune response, as well as the consequences of defects in this critical homeostatic mechanism in this review. (6) Understanding these facets of efferocytosis may shed light on the critical physiological and pathophysiological facets of efferocytosis.(5)

\section{Regulated Cell Death}

In general, cell death can be classified as regulated cell death (RCD) and accidental cell death (ACD).(7-11) Programmed cell death (PCD) is RCD that are entirely physiological. Importantly, stress-driven RCD is a technique for maintaining biological equilibrium, similar to adaptive stress responses. Adaptive stress responses, however, operate at the cellular level (which, by implication, facilitates the preservation of homeostasis at the organism or colony level), while RCD operates directly at the organism or colony level despite cellular homeostasis.(7) This homeostatic role includes the ability of dying cells to reveal or release molecules that warn the organism or colony about a potential threat, as well as the removal of useless or potentially harmful cells, referred as damage-associated molecular patterns (DAMPs) or alarmins.(12-15)

There are various modes of RCD as described in Figure 1, each with its own triggering stimuli and signalling moieties that are presented to the phagocyte, resulting in efferocytosis and a number of physiological outcomes, namely apoptosis, necroptosis, pyroptosis, and ferroptosis.

Apoptosis can be triggered by the intrinsic pathway occurs when the mitochondrial pathway is activated by cellular stress, and the extrinsic apoptosis occurs when death receptors on the cell surface are activated. The death receptor leads to the recruitment of pro-caspase 8 to the

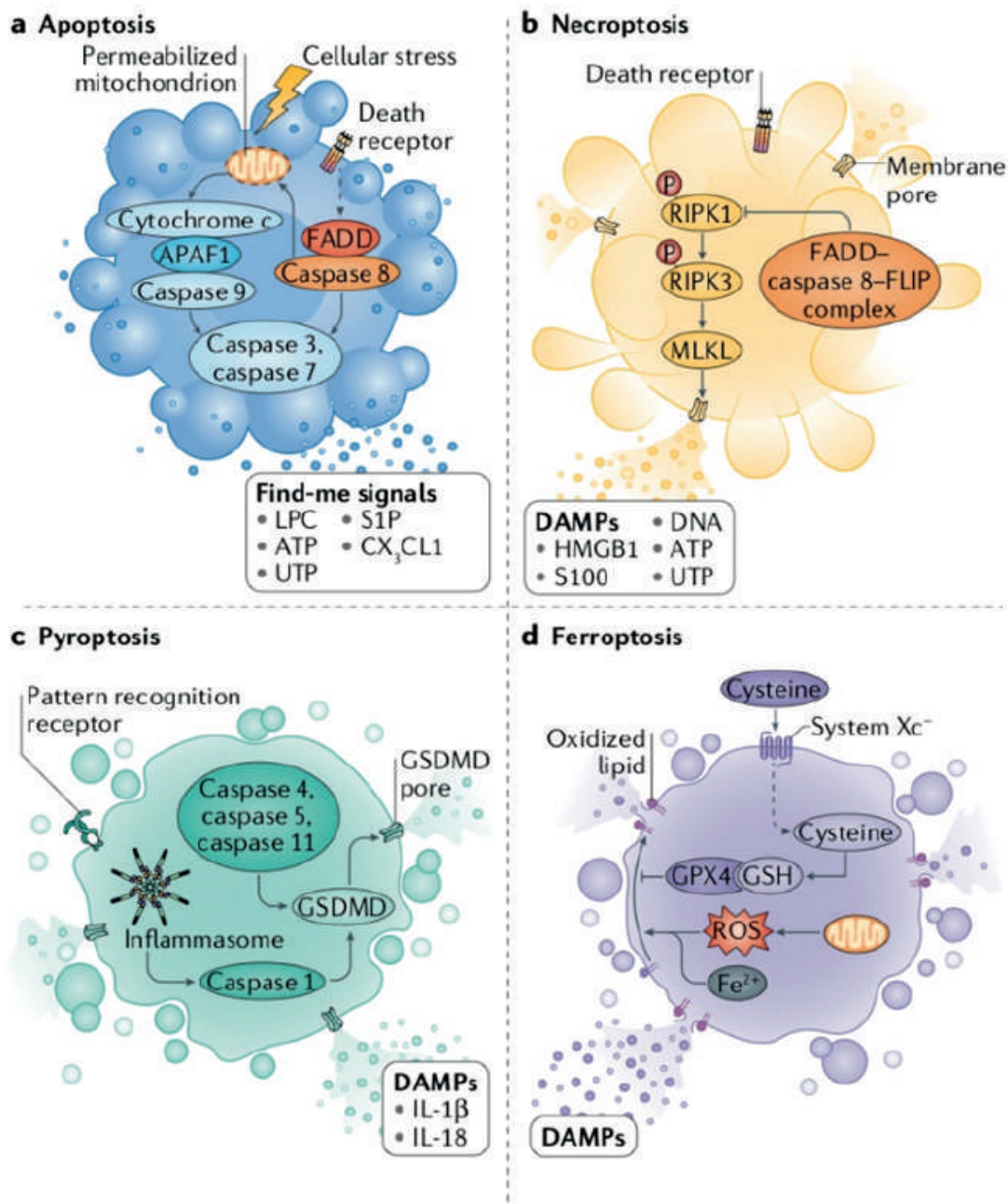

Figure 1. Modes of programmed cell death.(6) (Adapted with permission from Springer Nature). 
intracellular region via the adaptor protein FADD (FAS associated via death domain). The intrinsic pathway release of cytochrome $\mathrm{c}$ and activation of the initiator caspase 9. Both apoptotic pathway assemble upon activation of caspase 3 and 7. The activation of caspases during apoptosis release 'find-me' signals that that indicate their presence to mobilization apoptotic cells towards phagocytes.(5)

Extrinsic apoptotic receptors may also cause necroptosis, which is a controlled type of necrosis. The activation of Receptor Interacting Serine/Threonine Kinase (RIPK)1, which binds to and activates RIPK3 after autophosphorylation.(16) This causes activation of the pseudo-kinase mixed-lineage kinase domain-like (MLKL) which translocates to the cell membrane, and release of damage-associated molecular patterns (DAMPs) to recognize by phagocytes.(6)

Pyroptosis is triggered as response to infection, such as lipopolysaccharide on intracellular gram-negative bacteria was recognized by inflammatory caspases includes caspase 1, 4, 5 and 11. Activation this caspases cleave gasdermin D (GSDMD) resulting cell lysis. Pyroptosis and necroptosis leading to secretion of pro-inflammatory cytokines.(6)

Ferroptosis is programmed cell death dependent on iron. Through the Fenton reaction, free cytosolic iron can spread lipid peroxidation, and promote ferroptosis, indicated by membrane rupture caused by excessive amounts of lipid peroxides.(6)

Efferocytosis is important in RCD to maintain organisms homeostasis, and allows multicellular organisms to recycle cellular components.(16-19) Autophagydependent cell death (20-23), on the other side is a form of RCD that is dependent on the autophagic machinery or its components. Autophagic responses (which are tightly regulated at the transcriptional and post-translational levels) are often found at the center of stress adaptation (20,24-30), mediating cytoprotective (rather than cytotoxic) effects (31-36).

\section{Phagocytosis of Apoptotic Cells in Homeostasis}

The process of creating and sustaining a multicellular functioning organism is marked by the unceremonious formation and destruction of billions of cells, even from our earliest developmental stages.(37) Different tissues switch over differing numbers of apoptotic cells as part of normal homeostasis, with some tissues experiencing an impressively high rate of renewal. Such as hematopoiesis which generates billions of cells every day, because most of them have short lifespans (such as neutrophils); epithelial cells in the gastrointestinal tract, which occupy a region the size of a tennis court, are replaced every 4-5 days.(38) In certain cases, small parts of cells (rather than entire cells) are phagocytosed, such as those during neuronal pruning. There are also times when the rates of apoptosis in a given tissue exceeds the normal rates, such as those during infection or acute tissue injury.(39) Apoptosis, necroptosis, and pyroptosis are active mechanism that perform the cellular turnover as a continuous, genetically programmed operation, and it is critical to remove these unwanted and unneeded cellular corpses.(40)

Tissue-resident and recruited phagocytes play important roles in the clearance of cellular corpse. Under homeostatic circumstances, tissue-resident phagocytes mediate the clearance of the cellular "corpse." Both local and recruited phagocytes mediate increased cell death due to infection (such as during lung infection) or chronic "sterile" inflammation (for example atherosclerotic plaques). Failure to remove apoptotic cells at an early stage of death and development to a secondary necrotic state might cause tissue inflammation due to the loss of cellular contents or the exposure of previously buried intracellular compounds. (41) The cell-clearance machinery makes the crucial 'decision' on whether or not to activate an immune response to the dying cell in response to molecules released by and/or exposed on the dying cells. Then the phagocyte role in final decision to induce or suppress the inflammation. $(41,42)$

Professional, non-professional, and specialized phagocytes in our tissues are charged with clearing dying cells. Macrophages are the best professional phagocytes. Every tissue has sub-differentiated resident macrophages with their own name.(39) For instance, liver has kupffer cells to clear aged red blood cells (43); lungs have alveolar macrophages to clear apoptotic airway epithelial cells; and CNS has microglia for dying neurons clearance (44). Non-professional phagocytes are other types of resident cells, such as epithelial cells and fibroblasts, which may be a misnomer since these cells play an important role when professional phagocytes (the monocytes, macrophages, neutrophils, tissue dendritic cells and mast cells) are scarce, as in the mammary gland or intestinal epithelium.(45)

If we consider that one million adult human cells die every second, we will appreciate the enormity of the task that phagocytes face.(46) Furthermore, since this is a recurrent and natural occurrence in an organism's lifetime, the process of dead cell clearance must take place in a quiet manner so that the immune system is not overly alerted.(47) 
Efferocytosis is important in immune modulation, as well as the effect of various forms of cell death on the immune response.

Phagocytosis is a simple yet complex process for ingesting and eliminating pathogens, but it's also vital for removing apoptotic cells, making it essential for tissue homeostasis. The identification of the target particle, signaling to activate the internalization machinery, phagosome development, and phagolysosome maturation are the four key steps in phagocytosis. The use of modern molecular biology and microscopy techniques has given new insights into the cellular mechanisms of phagocytosis in recent years.(48)

The composition of the local 'clearance crew' influences the homeostatic removal of cellular 'corpses' within a tissue. Professional and non-professional phagocytes have been identified as phagocytes that consume apoptotic cells. We propose a third group based on existing evidence: specialized phagocytes. A beautiful series of studies now suggests that stem cells originating from the embryonic yolk sac colonize most tissues and contribute to the resident macrophage pool. $(49,50)$ During infection or injury, circulating monocytes may be recruited in addition to resident phagocytes. Recruited phagocytes may work together (or compete against) resident phagocytes to influence the immune response.(51)

Engulfment of apoptotic cells takes distinct phases, according to studies by several groups. To attract and/or activate the phagocytes, the dying cell first sends out 'findme' signals. The phagocytes then use unique engulfment receptors to differentiate the apoptotic cell from healthy living cells, recognizing 'eat-me' signals on the dying cell. Later the phagocytes will rearrangement the cytoskeletal to able to internalize the cellular "corpses". The ingested cargo is processed, and unique phagocyte responses are elicited, primarily the secretion of anti-inflammatory mediators that help dampen the local immune response.(51)

Inflammatory and/or homeostatic contexts have shown a plethora of apoptotic cell-recognition and engulfment receptors, including scavenger receptors, immunoglobulincontaining proteins, seven-transmembrane proteins, and tyrosine kinases. The fact that there are so many different types of engulfment receptors and how they operate is not yet understood. In certain respects, the diversity of engulfment receptors resembles that of accessory proteins involved in $\mathrm{T}$ cell-antigen-presenting cell interactions. Although the exposed phosphatidylserine (PtdSer) may have a role similar to a large histocompatibility complex molecule on an antigen-presenting cell, the difference between the phagocyte-apoptotic cell interaction and the T cell-antigenpresenting cell interface is the absence of a phagocyte antigen receptor. Instead, the receptor's role appears to be shared among the various engulfment receptors.(39)

Understanding the function of specific receptors is the first challenge in determining how apoptotic cell clearance controls tissue homeostasis. It's unclear if there's a 'preference' for using specific engulfment receptors or clearance mechanisms to distinguish between homeostatic apoptotic cell turnover and inflammatory apoptotic cell turnover. The anti-inflammatory responses are another challenge. Phagocytosis of apoptotic cells differs from other (such as bacteria or pathogens) because it is generally non-immunogenic and the mediator released is actively reduce inflammation in the local tissue milieu. However, how the molecular processes in phagocytes cause specific downstream effects are not yet identified.(52,53)

\section{The Dynamic of Apoptotic Cell Clearance}

The constant replacement of damaged or aged cells with new ones is needed to maintain tissue health and function. In reality, the average healthy adult is expected to lose 150 billion cells every day to apoptosis (out of the estimated 37.2 trillion cells in the human body), or around 0.4 percent of the body's cellular mass.(1) Efferocytosis, or the phagocytic clearance of apoptotic cells corpses, is essential for embryonic growth, organogenesis, tissue repair, and immunity. Furthermore, abnormal interstitial cell clearance is gradually being recognized as both a cause and a consequence of many diseases' pathobiology.(2,41,54-56) Macrophages, monocytes, and dendritic cells networks serve not only as immune sentinels for infection and tissue damage, but also essential mediators in the clearance of dead cells.(57-62) Professional phagocytes, on the other hand, are vastly outnumbered by non-phagocytic cells in most tissues. As a result, the location of these phagocytes inside a tissue is possibly critical for optimizing their interaction with dying cells.

The essence of the cellular environment and tissue function tend to be highly dependent on the interstitial positioning of macrophages and DC for engulfment of nucleated cells. In the case of lymphocyte growth and activation, a high number of leucocytes are die due to subsequent constriction of immune effector cells (63-65), thus macrophages and DC approach these tissue due to the signal from dead cells. During an adaptive immune response, stainable body macrophages are located near the 
light/dark boundary of the germinal centers in the spleen and lymph nodes, where they capture growing B cells that are experiencing apoptosis due to poor affinity or selfreactivity. During an adaptive immune response, stainable body macrophages are located near the light/dark boundary of the germinal centers in the spleen and lymph nodes, where they capture growing $\mathrm{B}$ cells that are experiencing apoptosis due to poor affinity or self-reactivity.(66-68) T lymphocyte production in the thymus results in a significant number of apoptotic $\mathrm{T}$ cells, while thymic macrophages are limited $<1 \%$ of total thymic cells, and DCs are even less in number. However, they provide efferocytosis throughout the organ, in a form of tiny cluster. $(58,59,69)$ The CD169 macrophages, which make up the majority of efferocytes in the bone marrow, are found in dense cellular regions near the sinuses.(70) These macrophages tend to be in the best position to multitask when it comes to engulfing apoptotic B cells, aged neutrophils, and erythrocytes.(2)

Apoptotic cells undergoing many morphological changes to be recognized by phagocytes which facilitate them to recognize and remove the apoptotic cell. Professional phagocytes such as macrophages and dendritic cells appear to phagocytose their targets as whole as shown when they engulf apoptotic thymocytes or neutrophils. $(71,72)$ Other cells such as fibroblasts and epithelial cells appear to engulf whole $\mathrm{AC}$ in a similar manner as those of macrophages and dendritic cells. $(45,73)$ However, under certain situations, a phagocyte is unable to fully engulf the dying target, presumably due to a size gap between the phagocyte and the target. Inflamed adipose tissue, for example, multiple macrophages appear to surround dying adipocytes by forming 'crown-like structures' around a single adipocyte, turn them into a "bite size" and ingesting smaller fragments of the dying cell.(74) The same case observed in the clearance of dying cells by fibroblasts when macrophages is absent.(71) In order to fragment dying cells into apoptotic bodies, a set of signalling process was needed, starting from cleavage and activation of the RHO-associated protein kinase 1 (ROCK1) by caspase 3 which then phosphorylates myosin light chain. This phosphorylation promote actomyosin contraction, and membrane blebbing resulting smaller sizes of apoptotic cell fragments known as apoptotic bodies (Figure 2).(75,76)

Apoptotic cells release "find-me" signal for example nucleotides or $\mathrm{CX} 3 \mathrm{C}$ chemokine ligand 1 (CX3CL1) and intercellular adhesion molecule 3 (ICAM3) before or during the onset of apoptosis to recruit phagocytes. Nucleotides are released from apoptotic cells through caspase-activated pannexin 1 (PANX1). Parallel with released "find-me" signal, apoptotic cells release "eat-me" signal (such as phosphatidylserine (PtdSer) and calreticulin (CRT) to detect by phagocytes for engulfment process. This process accompanied by CD31 as "don't eat-me" signal to mediate their recognition by phagocytes. Phagocytes cell surface receptors engage "eat-me" signals through brain-specific angiogenesis inhibitor (BAI-1) and CD91, or indirectly through ridging molecules (such as milk fat globule-EGF factor 8 (MFG-E8).(77)

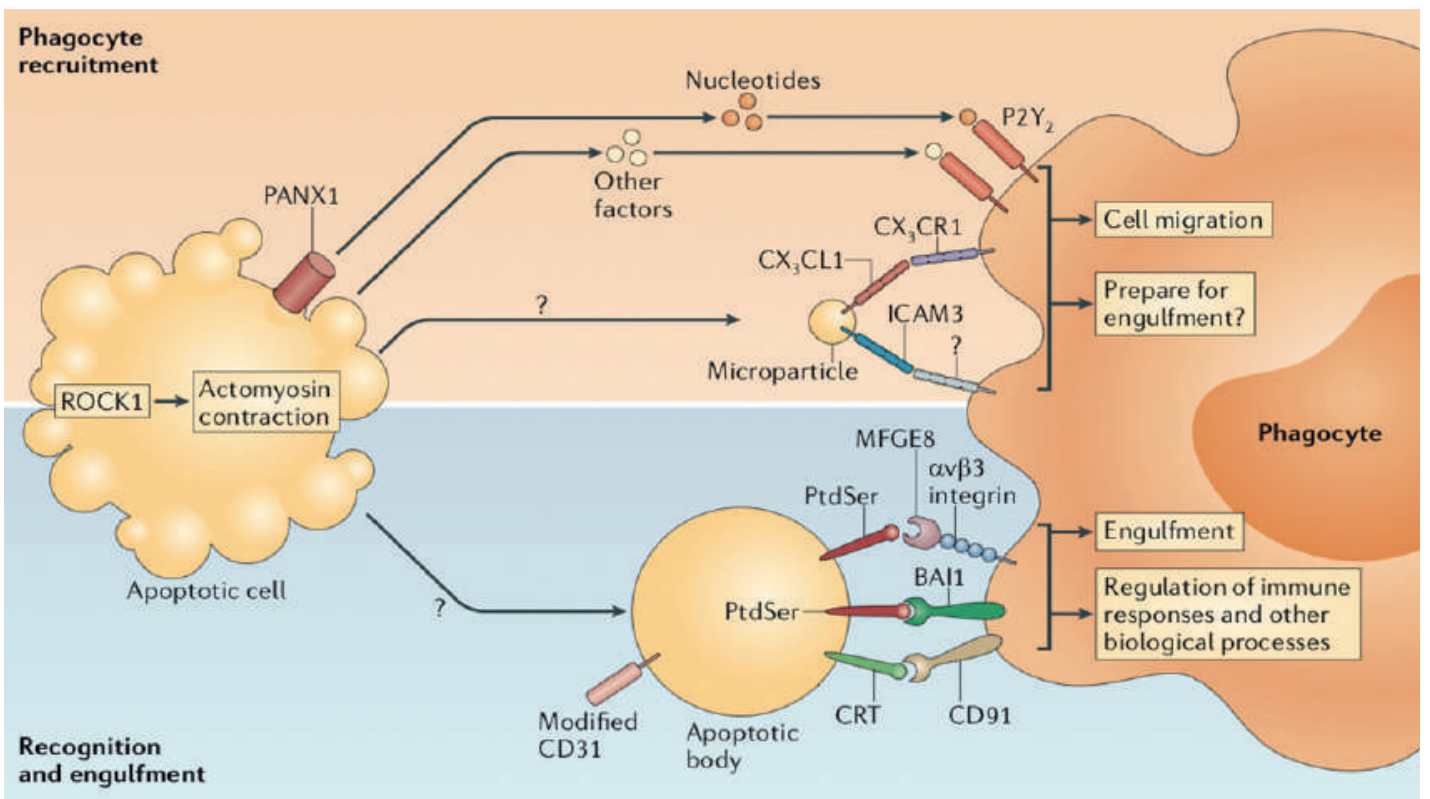

Figure 2. Phases of apoptotic cell clearance.(41) (Adapted with permission from Springer Nature). 
PtdSer is one key phagocytic uptake signal found in inner-membrane lipid surface.(77) Recent research suggests that phospholipid scramblase's (PLSCRs) calciumdependent and calcium-independent activities in apoptotic pathway disrupt the plasma membrane's aminophospholipid asymmetry. This activity encourage PtdSer exposure during apoptosis (78-80), suggests that PtdSer exposure is needed in certain level for detection by phagocyte (81).

Finally, the immunological result can be influenced by the timing of cell death and the length of apoptotic cellderived signals. As a result, depending on the circumstances under which the cell dies, apoptotic cells can promote immunity or tolerance. It's also worth noting that, in some cases, apoptotic cells can help with tissue growth and repair, as shown by myoblast fusion and wound healing. (41) The vastness of ways to mediate immune suppression and enforce tissue homeostasis is shown by our common knowledge of old and new phagocyte roles after apoptotic cell phagocytosis.(82)

\section{Necroptocys in Inflammation and Disease}

The definition of apoptosis as a programmed mechanism of cell death resulted in a dichotomous view of cell death: apoptosis (programmed cell death) or necrosis (passive cell death) in response to overwhelming chemical or physical insult. The morphological hallmarks of apoptosis and necrosis were initially used to characterize the processes: Necrotic cells swell and rupture, while apoptotic cells shrink and show nuclear condensation and membrane blebbing.(16)

As the initial step toward identifying the molecular processes that lead to necrosis-like cell death, RIPK1 is required for caspase-independent cell death in response to FAS ligand (FASL, also known as CD95L), TNFrelated apoptosis-inducing ligand (TRAIL; also known as TNFSF10), and TNF7 (Figure 3). Following that, RIPK1 was discovered to be the target of necrostatin-1 (Nec-1), a small-molecule inhibitor that prevented cell death caused by caspase inhibition. $(83,84)$ Thus, the term "necroptosis" was coined to describe a necrosis-like cell death mode that is dependent on RIPK1 kinase activity.

The initiator of receptor-mediated apoptotic cascade is caspase 8 . Knocking out FADD, and caspase 8 paralogue FLICE-like inhibitory protein (FLIP; or CFLAR or c-FLIP) induce unexpected death about embryonic day 10.5 (E10.5) of development, followed by excessive cell death.(85-88)
FLIP is an uncommon apoptotic factor causes a switch in the catalytic activity of caspase 8 from apoptosis activation to necroptosis suppression, and un-cleaved caspase 8 suppresses necroptosis without activating apoptosis. Genetic experiments demonstrated unequivocally that ablation of both RIPK3 and FADD, which inhibit both apoptotic and necroptotic signaling, was the only way to save FLIP-deficient animals' embryonic lethality.(89) The processes that govern necroptosis, on the other hand, include variables that alter the stability of RIPK1-RIPK3containing complexes as well as the inhibitory effect of the FADD-caspase 8-FLIP complex.

TNF-induced necroptosis is associated with a powerful burst of ROS production, which has been shown to be partially inhibited by the antioxidant butylated hydroxyanisole (BHA).(90-93). For a decade, it was assumed that unregulated ROS production was the mechanism by which necroptosis was carried out, with JUN aminoterminal kinase (JNK) signaling (94), NADPH oxidase 1 (NOX1) (95) and abnormal mitochondrial metabolism all being implicated (96).

Cells will release DAMPs during necroptosis, leading to the presumption that necroptosis is pro-inflammatory. In all of the experimental models studied, necroptosis was followed by significant inflammation. However, the release of DAMPs is just one way for RIPKs to cause inflammation, and new research suggests that the necrosome also plays a part in the direct development of pro-inflammatory cytokines.(16) Since RIPKs are involved in inflammation, cell survival, and cell death in a variety of tissues and cell types, they are expected to be involved in a variety of pathologies, as supported by research in a variety of disease models in animals.(16)

Apoptosis is a "clean" way for a cell to die. It doesn't induce any inflammation or immunology disorders. Dying cells were degraded into apoptotic body and then cleaned by phagocytes.(97-103) On the other hand, necroptosis and pyroptosis, are a much "dirtier" way. Both necroptosis and pyroptosis mediated by Mixed Lineage Kinase Domain Like Pseudokinase (MLKL), cause the plasma membrane to "burst," release their intracellular contents all together into the surrounding milieu and stimulate immune system pro-inflammatory responses. As a result, while apoptosis is anti-inflammatory, necroptosis and pyroptosis are proinflammatory.(104-106)

Necroptosis' in vivo has been proposed to play a role in a number of diseases, including atherosclerosis, pancreatitis, inflammatory bowel disease, and some cancers (107-109). The ability of necroptosis to target a specific cell 


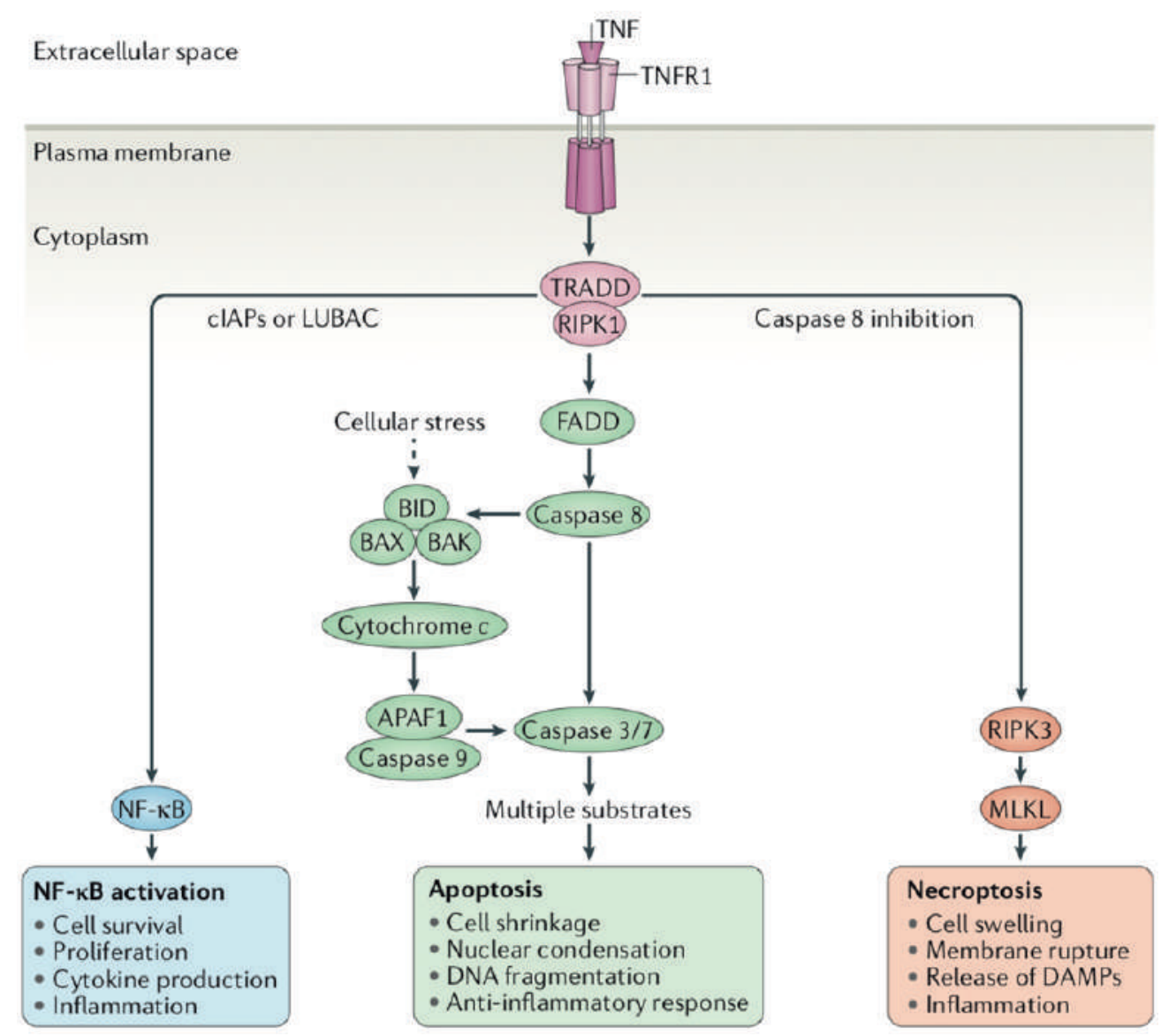

Figure 3. Apoptosis, necroptosis and inflammation can all be triggered by the same stimulus, such as TNF.(16) (Adapted with permission from Springer Nature).

death pathway has tremendous therapeutic promise and will likely be important as a therapy for inflammatory illness. (110)

\section{The Clearance of Dead Cells by Efferocytosis}

Cell shrinkage prior to cell death was related to a noninflammatory mechanism of cell clearance in early studies, while cell swelling prior to death was linked to an inflammatory response.(111-113) Each type has a significant impact on the biological consequences of cell death. Dying cells, release molecular signals to phagocytes and guide them to phagocyte the dying cells and to induce immune response. Despite its resemblance to phagocytosis, efferocytosis is a distinct mechanism involving complex receptors, bridging molecules, and downstream signaling pathways. $(115,116)$

Efferocytosis resembles macropinocytosis in its engulfment of apoptotic cells.(117) It is different from regular phagocytosis in term of its mediators, and its intracellular signalling pathways once an apoptotic cell is engulfed by phagocytes. During efferocytosis, GTPases Rac1 controls the engulfment of the apoptotic body, and the formation of a large phagosome called an efferosome that surrounds the newly swallowed apoptotic cell. A new GTPases known as Rab-17 seems to be involved in efferosome maturation in which. the end result is identical to phagocytosis: a series of lysosome fusion events delivers hydrolytic enzymes to the maturing efferosome. This, combined with its progressive acidification, creates harsh conditions that eventually kill the apoptotic cell. $(118,119)$

Efferocytosis is a highly regulated process that starts with the presence of an apoptotic cell. The exposure of PtdSer to the exofacial leaflet of the phospholipid membrane during the early stage of apoptosis $(120,121)$, provides a "find me" signal for chemokine release to recruit macrophages into the site of cell death. The macrophages then induce the bridge molecules and receptors expression to leash the "catch me" signals and the dying cells later engulfs by the macrophages while generates the large spacious efferosome in the "eat me" process, such as generate interleukin (IL)-10, transforming growth factor (TGF) $-\beta$, and Prostaglandin $\mathrm{E}_{2}$ (PGE2) during 
the engulfment of apoptotic cells, making efferocytosis anti-inflammatory.(122-125) Efferocytosis is critical for inflammatory resolution not only because it eliminates dead cells, relieves tissue obstruction, and prevents the release of phlogistic cellular contents, but also because it promotes tissue repair and wound healing.(126,127)

The cell releases soluble signals into the environment during apoptosis to attract macrophages and activate their scavenging ability. The "find me" signals are changed, such as lysophosphatidylcholine (LPC) (128) and sphingosine 1-phosphate (S1P); and nucleotides, such as ATP and UTP (129); and chemokines, such as CX3CL1 (also known as fractalkine) (130). The signal is depend on the type of phagocyte and the number of dead cells.(131) Furthermore, the variety of find-me signals indicates that dead cells are recognized specifically by macrophages due to intrinsic redundancy.

Apoptosis-specific "find-me signals" LPC and S1P Caspases 3 cleaves and activates calcium-independent phospholipase A2, which then synthesizes LPC from phosphatidylcholine throughout apoptosis.(128) While some other activated protein kinases SPK1 and SPK2 $(132,133)$, and phosphorylate the membrane lipid sphingosine to produce S1P. LPC is released following the activation of ATP-binding cassette transporter 1 (ABCA1).(134)

Non-apoptotic cell death compromises plasma membrane integrity, and surrounding cells are exposed to inflammatory signals released by the ruptured, dying cells, in comparison to apoptosis. On non-apoptotic cell death, pathogen-associated molecular patterns (PAMPs) was released when cells infected with intracellular pathogens, while DAMPs are produced by cells and can be released when they die. DAMPs cause inflammatory responses and may also function as macrophage chemoattractants. DAMPs include genomic and mitochondrial DNA, nuclear proteins (high-mobility group protein B (HMGB), histones), and other metabolically diverse individuals (135), cytoplasmic proteins (S100), cytokines (IL-1 $\alpha$, IL-33, IL-36) and other small molecules (ATP, UTP, uric acid crystals) (136). Furthermore, during pyroptosis, inflammasome-mediated caspase 1 activation produces the inflammatory cytokines IL$1 \beta$ and IL-18, leading to inflammatory immune activation after cellular death.(137) While dying cells display 'eat-me' signals on their cell surface, healthy neighbours cells bear 'don't-eat-me' signals to be recognized by phagocytes.(6)

A common feature of all kinds of cell death is the loss of phospholipid asymmetry in the plasma membrane. The inner leaflet of the plasma membrane of most stable cell types contains phosphatidylethanolamine and PtdSer, whereas the outer leaflet has phosphatidylcholine and sphingomyelin. In healthy cells, the ATP-dependent activity of the flippase ATP11, which limits PtdSer to the plasma membrane's inner leaflet and inhibits its lateral movement, is required for the creation and maintenance of membrane lipid asymmetry. (138) The tdSer exposure on the surfaces of apoptotic cells during apoptosis is promoted by caspase 3 cleavage of ATP11 coupled with caspase 3-dependent activation of the scramblase XK-related protein 8 (XKR8).(80)

Exposed lysophoshatidylcholine (LPC) on dying cells' plasma membranes may bind to IgM, which then binds to fragment crystallizable $(\mathrm{Fc})$ receptors on phagocytes, such as macrophages.(139) As a result, LPC is frequently used as a find-me and eat-me signal. Proteins located in the lumen of the endoplasmic reticulum, such as calreticulin, may be exposed at the plasma membrane of dying cells and function as an eat-me signal in the absence of don't-eat-me signals. (140) Calreticulin is identified by phagocytes via the LDL receptor-related protein 1 (LRP1; also known as CD91), which collaborates with complement component $\mathrm{C} 1 \mathrm{q}$ and mannose-binding lectin to identify it (MBL).(140,141)

Each stage of efferocytosis is regulated by molecular mechanisms that enable the engulfed cell to be rapidly broken down and the phagocyte to be recovered. Two primary mechanisms for actin reorganization exist during efferocytosis, and both of them converge on the central regulator, which is the RHO family small GTPase RAC1. The first system mediates RAC1 activation. The second one induce RAC1 activation via guanine nucleotide exchange factor (GEF) DOCK180, the phagocytic regulatory protein engulfment, and cell motility protein (ELMO).(142) The SH3 domain of DOCK180 is then able to interact with ELMO.(143) The DOCK180-ELMO complex acts as a GEF for RAC1, causing it to be activated. RAC1 can then direct localized actin polymerization necessary to coat or grab the cargo by activating WASP family nucleationpromoting proteins SCAR and WAVE, which recruit the ARP2/3 complex and work together to create an actin nucleation center after being activated by either method. (48) The ARP2/3 complex not only forms a nucleation center for de novo actin polymerization, but it also binds to existing actin filaments, enabling new actin synthesis while retaining actin networking and branching, which are essential for phagosome formation.(144)

Macrophages are professional phagocytes that play a role in innate immune responses, but they also play a role in homeostasis and disease. Detection of PAMPs by macrophages during infection results in the development of cytokines and chemokines, which promote the recruitment 
of other cells and initiate an immune response. Macrophages can promote or maintain adaptive immunity by degrading pathogen-derived antigens and presenting them to $\mathrm{T}$ cells. (145) Furthermore, macrophages sterilize tissue, resolve inflammation, and avoid further immune system activation by engulfing and degrading bacteria.(146)

\section{Defective Efferocytosis in Chronic Inflammation Diseases: Therapeutic Implication}

An effective efferocytosis assert three outcomes including the elimination of the inflammatory response, proposing selftolerance, and then activating the pro-resolving pathways. All these three outcomes will prevent secondary necrosis and the damaging release of pro-inflammatory mediators. However, when efferocytosis is disrupted, these functions are jeopardized, resulting in increased inflammation, slowed disease resolution, and disease progression. $(82,100,103,131,147)$

Pathogen invasion often results in host cell death, while the pathogens are survive in these dying cells. This pathogen may induce secondary necroptosis and spread the infection. Rapid efferocytosis in this case will depend on many factors such as the type of pathogen, and infected cells, the efferocytes involved, and also the host genetic polymorphism. $(146,148)$

The fact that efferocytosis has so much redundancy in the identification of dying cells emphasizes its significance in pathophysiology, as seen in Figure 4. For example in glomerulonephritis autoimmune disease losing milk fat globule-EGF factor 8 (MFG-E8) as a bridging molecule to binding with phagocyte lead efferocytosis impairment. The other factors affecting this impairment may involve losing levels of the efferocytosis receptor MER proto-oncogene
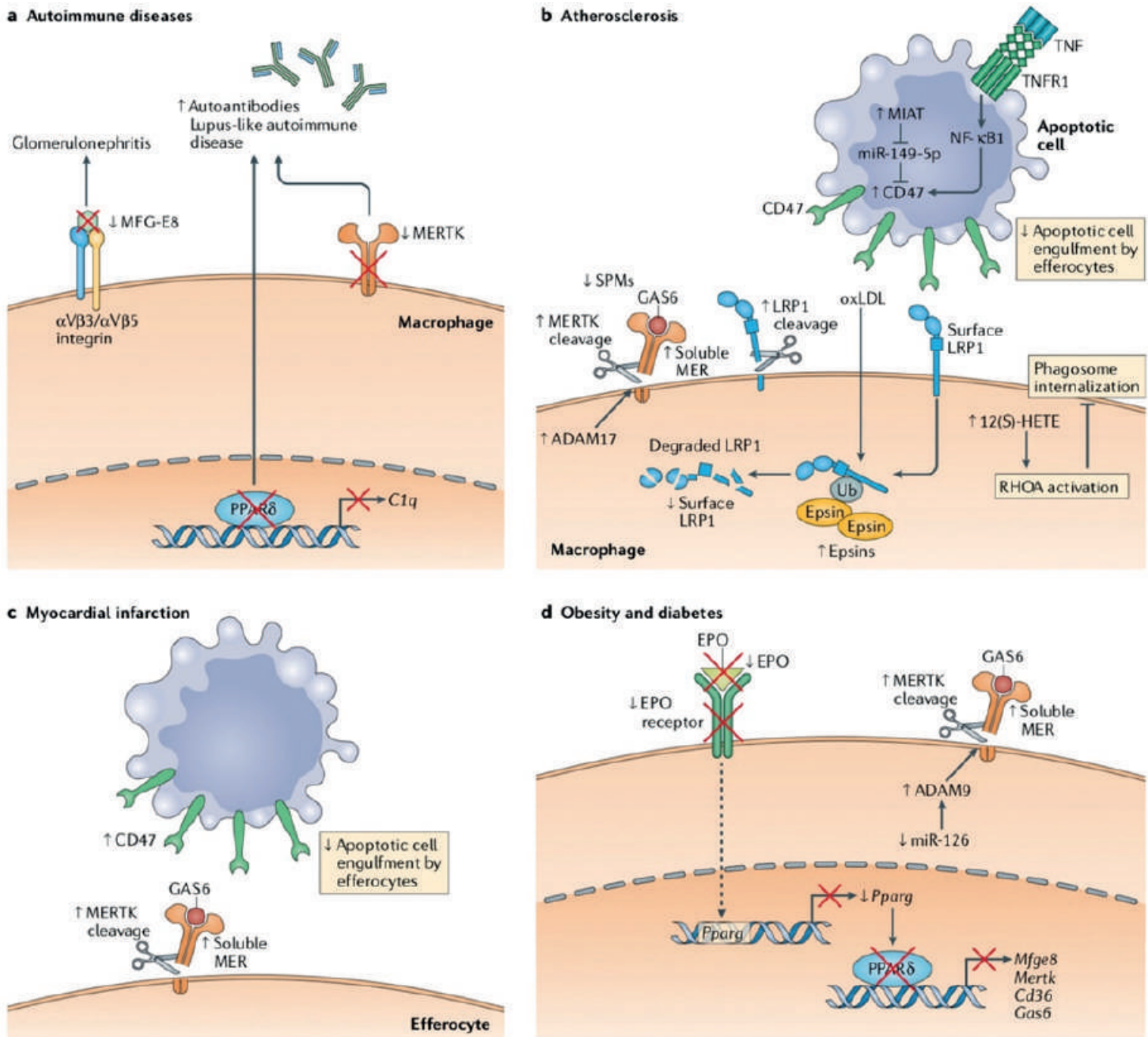

Figure 4. Mechanisms of impaired efferocytosis in disease.(5) (Adapted with permission from Springer Nature). 
tyrosine kinase (MERTK) or impairment of the efferocytosis bridging molecule $\mathrm{C} 1 \mathrm{q}$ by peroxisome proliferatoractivated receptor- $\delta$ (PPAR $\delta$ ).(148) Reduced levels of MERTK not only contribute to efferocytosis impairment in autoimmune disease, but also inflammation disease such as atherosclerosis and diabetes. Losing MERTK as results by cleavage by disintegrin and metalloproteinase domaincontaining protein 17 (ADAM 17) in atherosclerosis also plays an important role in this impairment. But in obesity and diabetes MERTK cleavage is driven by ADAM9 due to downregulation of miR-126. The MERTK cleavage product, soluble MER (sMER) may also play a role to worsening the efferocytosis impairment due to compete for the binding with growth arrest-specific protein 6 (GAS6) that is by apoptotic cells. Efferocytosis impairment in atherosclerosis may contributed by decreased levels of cell-surface LRP1 by epsin-mediated internalization of the receptor. In obesity and diabetes, reduction levels of both EPO and the EPO receptor also impairs efferocytosis efficiency due to direct to PPAR $\gamma$ expression. However, more research is needed to find out all these factors in these disease.(149)

Lipoxins, resolvins, protectins, and maresins are examples of specialized pro-resolving mediators (SPMs) that regulate inflammation resolution.(150) SPMs regulate inflammation and facilitate tissue repair without jeopardizing host defense.(150-152) Efferocytosis is an important cellular process in the resolution of inflammation. The absorption of ACs improves the biosynthesis of SPMs, and SPMs, in turn, promote the clearance of ACs in a feed-forward manner. (149-154) Defective efferocytosis and SPM biosynthesis are linked to chronic diseases such as atherosclerosis and cause the large necrotic cores to rupture easily. $(155,156)$

Necroptotic cells (NCs) have recently been identified as a major driver of atherosclerotic plaque necrosis.(157159) Since necroptosis is a pro-inflammatory type of cell death $(18,160)$, the accumulation of $\mathrm{NCs}$ in tissues may be harmful. NCs tend to be cleared in a different and less effective manner than ACs, according to previous research. $(159,161)$ Any effective pharmacologic treatments which improve efferocytosis will correct the atherosclerosis. (162-164)

Efferocytosis may be amenable to pharmacological targeting as a pathogen clearance and inflammation suppression mechanism. In reality, the idea of encouraging efferocytosis as a way to reduce plaque formation is already being discussed by the atherosclerosis field (127). Using the body's own pathogen-killing and immunoregulation processes to fight disease is an appealing strategy (147).
Efferocytosis malfunction causes significant illness, whereas efferocytosis activation, in combination with apoptotic cell clearance and LAP machinery activation, promotes immune silence by generating anti-inflammatory signals. Activating LAP and efferocytosis to promote an inflammatory response may be useful in the treatment of different cancers, since current data suggests that efferocytosis and LAP engagement are favorable in a variety of situations. Therapeutics targeting components of these pathways might augment existing cancer treatments such as checkpoint inhibition by increasing the immunogenicity of apoptotic tumor cells. As the science of efferocytosis and associated molecular pathways continues to grow, new insights into the activation and regulation of the response to dying cells are expected to lead to the creation of novel therapy paradigms for cancer, autoimmunity, dementia, and beyond.(6)

\section{Conclusion}

Efferocytosis, or the removal of apoptotic cells by professional, non-professional and also specialized phagocytes, is essential for tissue homeostasis. Multiple forms of cell death have been studied, each which has its own mechanism with a different pathway depending on the environment. Clearing dead cells and their associated cellular debris is important in the physiology as billions of cells die during mammalian embryogenesis as part of organ development and in adult to maintain tissue homeostasis.. The connections between efferocytosis and the resolution of inflammation will shed a great impact in health and disease.

\section{Authors Contribution}

CAP and AM were involved in drafting, writing, and revising the manuscript; MIB, KD, and AW were supervising dan giving critical suggestions to impove the manuscript; AW was involved in proposing the frame and concepting the ideas.

\section{References}

1. Bianconi E, Piovesan A, Facchin F, Beraudi A, Casadei R, Frabetti F, et al. An estimation of the number of cells in the human body. Ann Hum Biol. 2013; 40: 463-71.

2. Elliott MR, Ravichandran KS. The dynamics of apoptotic cell clearance. Dev Cell. 2016; 38: 147-60.

3. Kasikara C, Doran AC, Cai B, Tabas I. The role of non-resolving 
inflammation in atherosclerosis. J Clin Invest. 2018; 128: 2713-23.

4. Fredman G, Tabas I. Boosting inflammation resolution in atherosclerosis: the next frontier for therapy. Am J Pathol. 2017; 187: 1211-21.

5. Doran AC, Yurdagul A, Tabas I. Efferocytosis in health and disease. Nat Rev Immunol. 2020; 20: 254-67.

6. Boada-Romero E, Martinez J, Heckmann BL, Green DR. The clearance of dead cells by efferocytosis. Nat Rev Mol Cell Biol. 2020; 21: 398-414.

7. Galluzzi L, Bravo-San Pedro JM, Kepp O, Kroemer G. Regulated cell death and adaptive stress responses. Cell Mol Life Sci. 2016; 73: 2405-10.

8. Fuchs Y, Steller H. Programmed cell death in animal development and disease. Cell. 2011; 147: 742-58.

9. Galluzzi L, López-Soto A, Kumar S, Kroemer G. Caspases connect cell-death signaling to organismal homeostasis. Immunity. 2016; 44: 221-31.

10. Jorgensen I, Rayamajhi M, Miao EA. Programmed cell death as a defence against infection. Nat Rev Immunol. 2017; 17: 151-64.

11. Nagata S, Tanaka M. Programmed cell death and the immune system. Nat Rev Immunol. 2017; 17: 333-40.

12. West AP, Shadel GS. Mitochondrial DNA in innate immune responses and inflammatory pathology. Nat Rev Immunol. 2017; 17: 363-75.

13. Krysko DV, Garg AD, Kaczmarek A, Krysko O, Agostinis P, Vandenabeele P. Immunogenic cell death and DAMPs in cancer therapy. Nat Rev Cancer. 2012; 12: 860-75.

14. Galluzzi L, Kepp O, Kroemer G. Mitochondria: master regulators of danger signalling. Nat Rev Mol Cell Biol. 2012; 13: 780-8.

15. McDonald B, Pittman K, Menezes GB, Hirota SA, Slaba I, Waterhouse $\mathrm{CCM}$, et al. Intravascular danger signals guide neutrophils to sites of sterile inflammation. Science. 2010; 330: 362-6.

16. Weinlich R, Oberst A, Beere HM, Green DR. Necroptosis in development, inflammation and disease. Nat Rev Mol Cell Biol. 2017; 18: 127-36.

17. Conrad M, Angeli JPF, Vandenabeele P, Stockwell BR. Regulated necrosis: disease relevance and therapeutic opportunities. Nat Rev Drug Discov. 2016; 15: 348-66.

18. Wallach D, Kang T-B, Dillon CP, Green DR. Programmed necrosis in inflammation: toward identification of the effector molecules Science. 2016; 352: aaf2154. doi: 10.1126/science.aaf2154.

19. Galluzzi L, Kepp O, Chan FK-M, Kroemer G. Necroptosis: mechanisms and relevance to disease. Annu Rev Pathol. 2017; 12 103-30.

20. Galluzzi L, Baehrecke EH, Ballabio A, Boya P, Bravo-San Pedro JM, Cecconi $\mathrm{F}$, et al. Molecular definitions of autophagy and related processes. EMBO J. 2017; 36: 1811-36.

21. Zhang H, Baehrecke EH. Eaten alive: novel insights into autophagy from multicellular model systems. Trends Cell Biol. 2015; 25: 37687.

22. Sharma K, Le N, Alotaibi M, Gewirtz DA. Cytotoxic autophagy in cancer therapy. Int J Mol Sci. 2014; 15: 10034-51.

23. Das G, Shravage BV, Baehrecke EH. Regulation and function of autophagy during cell survival and cell death. Cold Spring Harb Perspect Biol. 2012; 4(6): a008813. doi: 10.1101/cshperspect. a008813.

24. Füllgrabe J, Ghislat G, Cho DH, Rubinsztein DC. Transcriptional regulation of mammalian autophagy at a glance. J Cell Sci. 2016; 129: 3059-66.

25. Baek SH, Kim KI. Epigenetic control of autophagy: nuclear events gain more attention. Mol Cell. 2017; 65: 781-5.

26. Pietrocola F, Izzo V, Niso-Santano M, Vacchelli E, Galluzzi L, Maiuri MC, et al. Regulation of autophagy by stress-responsive transcription factors. Semin Cancer Biol. 2013; 23: 310-22.

27. Füllgrabe J, Klionsky DJ, Joseph B. The return of the nucleus: transcriptional and epigenetic control of autophagy. Nat Rev Mol Cell Biol. 2014; 15: 65-74.

28. Klionsky DJ, Emr SD. Autophagy as a regulated pathway of cellular degradation. Science. 2000; 290: 1717-21.

29. Galluzzi L, Pietrocola F, Levine B, Kroemer G. Metabolic control of autophagy. Cell. 2014; 159: 1263-76.

30. Kaur J, Debnath J. Autophagy at the crossroads of catabolism and anabolism. Nat Rev Mol Cell Biol. 2015; 16: 461-72.

31. Galluzzi L, Pietrocola F, Bravo-San Pedro JM, Amaravadi RK, Baehrecke EH, Cecconi F, et al. Autophagy in malignant transformation and cancer progression. EMBO J. 2015; 34: 856-80.

32. Levy JMM, Towers CG, Thorburn A. Targeting autophagy in cancer. Nat Rev Cancer. 2017; 17: 528-42.

33. Mulcahy Levy JM, Zahedi S, Griesinger AM, Morin A, Davies $\mathrm{KD}$, Aisner DL, et al. Autophagy inhibition overcomes multiple mechanisms of resistance to BRAF inhibition in brain tumors. eLife. 2017; 6: e19671. doi: 10.7554/eLife.19671.

34. Pagotto A, Pilotto G, Mazzoldi EL, Nicoletto MO, Frezzini S, Pastò A, et al. Autophagy inhibition reduces chemoresistance and tumorigenic potential of human ovarian cancer stem cells. Cell Death Dis. 2017; 8: e2943. doi: 10.1038/cddis.2017.327.

35. Sica V, Galluzzi L, Bravo-San Pedro JM, Izzo V, Maiuri MC, Kroemer G. Organelle-specific initiation of autophagy. Mol Cell. 2015; 59: $522-39$.

36. Liu P, Liu K, Gu H, Wang W, Gong J, Zhu Y, et al. High autophagic flux guards ESC identity through coordinating autophagy machinery gene program by FOXO1. Cell Death Differ. 2017; 24: 1672-80.

37. Green DR. Means to an End: Apoptosis and Other Cell Death Mechanisms. New York: Cold Spring Harbor Laboratory Press; 2011

38. Monks J, Rosner D, Geske FJ, Lehman L, Hanson L, Neville MC, et al. Epithelial cells as phagocytes: apoptotic epithelial cells are engulfed by mammary alveolar epithelial cells and repress inflammatory mediator release. Cell Death Differ. 2005; 12: 10714.

39. Arandjelovic S, Ravichandran KS. Phagocytosis of apoptotic cells in homeostasis. Nat Immunol. 2015; 16: 907-17.

40. Martinez J. Prix fixe: efferocytosis as a four-course meal. In: Nagata S, Nakano H, editors. Apoptotic and Non-apoptotic Cell Death. Berlin: Springer International Publishing; 2015. p.1-36.

41. Poon IKH, Lucas CD, Rossi AG, Ravichandran KS. Apoptotic cell clearance: basic biology and therapeutic potential. Nat Rev Immunol. 2014; 14: 166-80.

42. Nagata S. Autoimmune diseases caused by defects in clearing dead cells and nuclei expelled from erythroid precursors. Immunol Rev. 2007; 220: 237-50

43. Dini L, Pagliara P, Carlà EC. Phagocytosis of apoptotic cells by liver: a morphological study. Microsc Res Tech. 2002; 57: 530-40.

44. Bilimoria PM, Stevens B. Microglia function during brain development: New insights from animal models. Brain Res. 2015; 1617: 7-17.

45. Juncadella IJ, Kadl A, Sharma AK, Shim YM, Hochreiter-Hufford A, Borish L, et al. Apoptotic cell clearance by bronchial epithelial cells critically influences airway inflammation. Nature. 2013; 493: $547-51$.

46. Ravichandran KS. Find-me and eat-me signals in apoptotic cell clearance: progress and conundrums. J Exp Med. 2010; 207: 180717.

47. Hart Sp, Dransfield I, Rossi A. Phagocytosis of apoptotic cells. Methods. 2008; 44: 280-5. 
48. Rosales C, Uribe-Querol E. Phagocytosis: a fundamental process in immunity. Biomed Res Int. 2017; 2017: 9042851. doi: $10.1155 / 2017 / 9042851$.

49. Gomez Perdiguero E, Klapproth K, Schulz C, Busch K, Azzoni E, Crozet L, et al. Tissue-resident macrophages originate from yolksac-derived erythro-myeloid progenitors. Nature. 2015; 518: 54751.

50. Hoeffel G, Chen J, Lavin Y, Low D, Almeida FF, See P, et al. C-Myb+ erythro-myeloid progenitor-derived fetal monocytes give rise to adult tissue-resident macrophages. Immunity. 2015; 42: 665-78.

51. Uderhardt S, Herrmann M, Oskolkova OV, Aschermann S, Bicker $\mathrm{W}$, Ipseiz N, et al. 12/15-lipoxygenase orchestrates the clearance of apoptotic cells and maintains immunologic tolerance. Immunity. 2012; 36: 834-46.

52. Fond AM, Lee CS, Schulman IG, Kiss RS, Ravichandran KS. Apoptotic cells trigger a membrane-initiated pathway to increase ABCA1. J Clin Invest. 2015; 125: 2748-58.

53. Henson PM. Dampening inflammation. Nat Immunol. 2005; 6: 117981.

54. Green DR, Oguin TH, Martinez J. The clearance of dying cells: table for two. Cell Death Differ. 2016; 23: 915-26.

55. Nagata S, Hanayama R, Kawane K. Autoimmunity and the clearance of dead cells. Cell. 2010; 140: 619-30.

56. Saas P, Kaminski S, Perruche S. Prospects of apoptotic cellbased therapies for transplantation and inflammatory diseases. Immunotherapy. 2013; 5: 1055-73.

57. Davies LC, Jenkins SJ, Allen JE, Taylor PR. Tissue-resident macrophages. Nat Immunol. 2013; 14: 986-95.

58. Dzhagalov IL, Chen KG, Herzmark P, Robey EA. Elimination of self-reactive $T$ cells in the thymus: a timeline for negative selection. PLOS Biology. 2013; 11(5): e1001566. doi: 10.1371/journal. pbio. 1001566 .

59. Kim HJ, Alonzo ES, Dorothee G, Pollard JW, Sant'Angelo DB. Selective depletion of eosinophils or neutrophils in mice impacts the efficiency of apoptotic cell clearance in the thymus. PLoS ONE. 2010; 5: e11439. doi: 10.1371/journal.pone.0011439.

60. Okabe Y, Medzhitov R. Tissue-specific signals control reversible program of localization and functional polarization of macrophages. Cell. 2014; 157: 832-44.

61. Perdiguero EG, Geissmann F. The development and maintenance of resident macrophages. Nat Immunol. 2016; 17: 2-8.

62. Westphalen K, Gusarova GA, Islam MN, Subramanian M, Cohen TS, Prince AS, et al. Sessile alveolar macrophages communicate with alveolar epithelium to modulate immunity. Nature. 2014; 506: 503-6.

63. Garrod KR, Moreau HD, Garcia Z, Lemaître F, Bouvier I, Albert $\mathrm{ML}$, et al. Dissecting T cell contraction in vivo using a genetically encoded reporter of apoptosis. Cell Rep. 2012; 2: 1438-47.

64. Klein L, Kyewski B, Allen PM, Hogquist KA. Positive and negative selection of the T cell repertoire: what thymocytes see (and don't see). Nat Rev Immunol. 2014; 14: 377-91.

65. LeBien TW, Tedder TF. B lymphocytes: how they develop and function. Blood. 2008; 112: 1570-80.

66. Gray EE, Cyster JG. Lymph node macrophages. J Innate Immun. 2012; 4: 424-36. doi: 10.1159/000337007.

67. Hanayama R, Tanaka M, Miyasaka K, Aozasa K, Koike M, Uchiyama $\mathrm{Y}$, et al. Autoimmune disease and impaired uptake of apoptotic cells in MFG-E8-deficient mice. Science. 2004; 304: 1147-50.

68. Vinuesa CG, Sanz I, Cook MC. Dysregulation of germinal centres in autoimmune disease. Nat Rev Immunol. 2009; 9: 845-57.

69. Tacke R, Hilgendorf I, Garner H, Waterborg C, Park K, Nowyhed $\mathrm{H}$, et al. The transcription factor NR4A1 is essential for the development of a novel macrophage subset in the thymus. Sci Rep. 2015; 5: 10055. doi: 10.1038/srep10055.

70. Morrison SJ, Scadden DT. The bone marrow niche for haematopoietic stem cells. Nature. 2014; 505: 327-34.

71. Wood W, Turmaine M, Weber R, Camp V, Maki RA, McKercher SR, et al. Mesenchymal cells engulf and clear apoptotic footplate cells in macrophageless PU.1 null mouse embryos. Development. 2000; 127: 5245-52.

72. Parnaik R, Raff MC, Scholes J. Differences between the clearance of apoptotic cells by professional and non-professional phagocytes. Curr Biol. 2000; 10: 857-60.

73. Monks J, Smith-Steinhart C, Kruk ER, Fadok VA, Henson PM Epithelial cells remove apoptotic epithelial cells during postlactation involution of the mouse mammary gland. Biol Reprod. 2008; 78: 586-94.

74. Cinti S, Mitchell G, Barbatelli G, Murano I, Ceresi E, Faloia E, et al. Adipocyte death defines macrophage localization and function in adipose tissue of obese mice and humans. J Lipid Res. 2005; 46: 2347-55.

75. Sebbagh M, Renvoizé C, Hamelin J, Riché N, Bertoglio J, Bréard J. Caspase-3-mediated cleavage of ROCK I induces MLC phosphorylation and apoptotic membrane blebbing. Nat Cell Biol. 2001; 3: 346-52.

76. Coleman ML, Sahai EA, Yeo M, Bosch M, Dewar A, Olson MF. Membrane blebbing during apoptosis results from caspase-mediated activation of ROCK I. Nat Cell Biol. 2001; 3: 339-45.

77. Fadok VA, Voelker DR, Campbell PA, Cohen JJ, Bratton DL, Henson PM. Exposure of phosphatidylserine on the surface of apoptotic lymphocytes triggers specific recognition and removal by macrophages. J Immunol. 1992; 148: 2207-16.

78. Verhoven B, Schlegel RA, Williamson P. Mechanisms of phosphatidylserine exposure, a phagocyte recognition signal, on apoptotic T lymphocytes. J Exp Med. 1995; 182: 1597-601.

79. Bratton DL, Fadok VA, Richter DA, Kailey JM, Guthrie LA, Henson PM. Appearance of phosphatidylserine on apoptotic cells requires calcium-mediated nonspecific flip-flop and is enhanced by loss of the aminophospholipid translocase. J Biol Chem. 1997; 272: 26159-65.

80. Suzuki J, Denning DP, Imanishi E, Horvitz HR, Nagata S. Xk-related protein 8 and CED-8 promote phosphatidylserine exposure in apoptotic cells. Science. 2013; 341: 403-6.

81. Borisenko GG, Matsura T, Liu S-X, Tyurin VA, Jianfei J, Serinkan FB, et al. Macrophage recognition of externalized phosphatidylserine and phagocytosis of apoptotic Jurkat cells--existence of a threshold. Arch Biochem Biophys. 2003; 413: 41-52.

82. Blander JM. The many ways tissue phagocytes respond to dying cells. Immunol Rev. 2017; 277: 158-73.

83. Degterev A, Huang Z, Boyce M, Li Y, Jagtap P, Mizushima N, et $a l$. Chemical inhibitor of nonapoptotic cell death with therapeutic potential for ischemic brain injury. Nat Chem Biol. 2005; 1: 112-9.

84. Degterev A, Hitomi J, Germscheid M, Ch'en IL, Korkina O, Teng X, et al. Identification of RIP1 kinase as a specific cellular target of necrostatins. Nat Chem Biol. 2008; 4: 313-21.

85. Yeh WC, de la Pompa JL, McCurrach ME, Shu HB, Elia AJ, Shahinian A, et al. FADD: essential for embryo development and signaling from some, but not all, inducers of apoptosis. Science. 1998; 279: 1954-8.

86. Yeh WC, Itie A, Elia AJ, $\mathrm{Ng} \mathrm{M}$, Shu HB, Wakeham A, et al. Requirement for Casper (c-FLIP) in regulation of death receptorinduced apoptosis and embryonic development. Immunity. 2000; 12: $633-42$.

87. Walsh CM, Wen BG, Chinnaiyan AM, O'Rourke K, Dixit VM, 
Hedrick SM. A role for FADD in T cell activation and development. Immunity. 1998; 8: 439-49.

88. Varfolomeev EE, Schuchmann M, Luria V, Chiannilkulchai N, Beckmann JS, Mett IL, et al. Targeted disruption of the mouse Caspase 8 gene ablates cell death induction by the TNF receptors, Fas/Apo1, and DR3 and is lethal prenatally. Immunity. 1998; 9: 267-76.

89. Dillon CP, Oberst A, Weinlich R, Janke LJ, Kang T-B, Ben-Moshe $\mathrm{T}$, et al. Survival function of the FADD-CASPASE-8-cFLIPL complex. Cell Rep. 2012; 1(5): 401-7.

90. Vercammen D, Brouckaert G, Denecker G, Van de Craen M, Declercq $\mathrm{W}$, Fiers W, et al. Dual signaling of the fas receptor: initiation of both apoptotic and necrotic cell death pathways. J Exp Med. 1998; 188: 919-30.

91. Vercammen D, Beyaert R, Denecker G, Goossens V, Van Loo G, Declercq W, et al. Inhibition of caspases increases the sensitivity of L929 cells to necrosis mediated by tumor necrosis factor. J Exp Med. 1998; 187: 1477-85.

92. Lin Y, Choksi S, Shen HM, Yang QF, Hur GM, Kim YS, et al. Tumor necrosis factor-induced nonapoptotic cell death requires receptorinteracting protein-mediated cellular reactive oxygen species accumulation. J Biol Chem. 2004; 279: 10822-8.

93. Kalai M, Van Loo G, Vanden Berghe T, Meeus A, Burm W, Saelens $\mathrm{X}$, et al. Tipping the balance between necrosis and apoptosis in human and murine cells treated with interferon and dsRNA. Cell Death Differ. 2002; 9: 981-94.

94. Ventura JJ, Cogswell P, Flavell RA, Baldwin AS, Davis RJ. JNK potentiates TNF-stimulated necrosis by increasing the production of cytotoxic reactive oxygen species. Genes Dev. 2004; 18: 2905-15.

95. Kim YS, Morgan MJ, Choksi S, Liu Z. TNF-induced activation of the Nox1 NADPH oxidase and its role in the induction of necrotic cell death. Mol Cell. 2007; 26: 675-87.

96. Zhang DW, Shao J, Lin J, Zhang N, Lu BJ, Lin SC, et al. RIP3, an energy metabolism regulator that switches TNF-induced cell death from apoptosis to necrosis. Science. 2009; 325: 332-6.

97. Chen W, Frank ME, Jin W, Wahl SM. TGF-beta released by apoptotic $\mathrm{T}$ cells contributes to an immunosuppressive milieu. Immunity. 2001; 14: 715-25.

98. Ferguson TA, Herndon J, Elzey B, Griffith TS, Schoenberger S, Green DR. Uptake of apoptotic antigen-coupled cells by lymphoid dendritic cells and cross-priming of $\mathrm{CD} 8(+) \mathrm{T}$ cells produce active immune unresponsiveness. J Immunol. 2002; 168: 5589-95.

99. Green DR. The cell's dilemma, or the story of cell death: an entertainment in three acts. FEBS J. 2016; 283: 2568-76.

100. Green DR, Ferguson T, Zitvogel L, Kroemer G. Immunogenic and tolerogenic cell death. Nat Rev Immunol. 2009; 9: 353-63.

101. Griffith TS, Kazama H, VanOosten RL, Earle JK, Herndon JM, Green DR, et al. Apoptotic cells induce tolerance by generating helpless CD8+ T cells that produce TRAIL. J Immunol. 2007; 178: 2679-87.

102. Griffith TS, Yu X, Herndon JM, Green DR, Ferguson TA. CD95induced apoptosis of lymphocytes in an immune privileged site induces immunological tolerance. Immunity. 1996; 5: 7-16.

103. Voll RE, Herrmann M, Roth EA, Stach C, Kalden JR, Girkontaite I. Immunosuppressive effects of apoptotic cells. Nature. 1997; 390: $350-1$.

104. Pasparakis M, Vandenabeele P. Necroptosis and its role in inflammation. Nature. 2015; 517: 311-20.

105. Man SM, Karki R, Kanneganti TD. Molecular mechanisms and functions of pyroptosis, inflammatory caspases and inflammasomes in infectious diseases. Immunol Rev. 2017; 277: 61-75.

106. Chang W, Lin J, Dong J, Li D. Pyroptosis: an inflammatory cell death implicates in atherosclerosis. Med Hypotheses. 2013; 81: 484-6.
107. Vanden Berghe T, Linkermann A, Jouan-Lanhouet S, Walczak H, Vandenabeele P. Regulated necrosis: the expanding network of nonapoptotic cell death pathways. Nat Rev Mol Cell Biol. 2014; 15: 135-47.

108. Linkermann A, Green DR. Necroptosis. N Engl J Med. 2014; 370 : 455-65.

109. Hanson B. Necroptosis: A new way of dying? Cancer Biol Ther. 2016; 17: 899-910.

110. Heckmann BL. Crashing the computer: apoptosis vs. necroptosis in neuroinflammation. Cell Death Differ. 2019; 26: 41-52.

111. Kerr JF, Wyllie AH, Currie AR. Apoptosis: a basic biological phenomenon with wide-ranging implications in tissue kinetics. Br J Cancer. 1972; 26: 239-57.

112. Majno G, Joris I. Apoptosis, oncosis, and necrosis. An overview of cell death. Am J Pathol. 1995; 146: 3-15.

113. Wyllie AH, Kerr JFR, Currie AR. Cell death: the significance of apoptosis. In: International Review of Cytology. Amsterdam: Elsevier; 1980. p.251-306.

114. Galluzzi L, Vitale I, Aaronson SA, Abrams JM, Adam D, Agostinis P, et al. Molecular mechanisms of cell death: recommendations of the Nomenclature Committee on Cell Death 2018. Cell Death Differ. 2018; 25: 486-541.

115. Jaumouillé V, Grinstein S. Receptor mobility, the cytoskeleton, and particle binding during phagocytosis. Curr Opin Cell Biol. 2011; 23: 22-9.

116. Underhill DM, Goodridge HS. Information processing during phagocytosis. Nat Rev Immunol. 2012; 12: 492-502.

117. Hoffmann PR, deCathelineau AM, Ogden CA, Leverrier Y, Bratton DL, Daleke DL, et al. Phosphatidylserine (PS) induces PS receptormediated macropinocytosis and promotes clearance of apoptotic cells. J Cell Biol. 2001; 155: 649-59.

118. Kinchen JM, Ravichandran KS. Phagosome maturation: going through the acid test. Nat Rev Mol Cell Biol. 2008; 9: 781-95.

119. Lu N, Zhou Z. Membrane trafficking and phagosome maturation during the clearance of apoptotic cells. Int Rev Cell Mol Biol; 293: 269-309.

120. Korns D, Frasch SC, Fernandez-Boyanapalli R, Henson PM, Bratton DL. Modulation of macrophage efferocytosis in inflammation. Front Immunol. 2011; 2: 57. doi: 10.3389/fimmu.2011.00057.

121. Cullen SP, Henry CM, Kearney CJ, Logue SE, Feoktistova M, Tynan GA, et al. Fas/CD95-induced chemokines can serve as "find-me" signals for apoptotic cells. Mol Cell. 2013; 49: 1034-48.

122. Fadok VA, Bratton DL, Konowal A, Freed PW, Westcott JY, Henson PM. Macrophages that have ingested apoptotic cells in vitro inhibit proinflammatory cytokine production through autocrine/paracrine mechanisms involving TGF-beta, PGE2, and PAF. J Clin Invest. 1998; 101: 890-8.

123. Kim S, Elkon KB, Ma X. Transcriptional suppression of interleukin-12 gene expression following phagocytosis of apoptotic cells. Immunity. 2004; 21: 643-53.

124. Mukundan L, Odegaard JI, Morel CR, Heredia JE, Mwangi JW, Ricardo-Gonzalez RR, et al. PPAR-delta senses and orchestrates clearance of apoptotic cells to promote tolerance. Nat Med. 2009; 15: 1266-72.

125. Xiao YQ, Freire-de-Lima CG, Schiemann WP, Bratton DL, Vandivier RW, Henson PM. Transcriptional and translational regulation of TGF-beta production in response to apoptotic cells. J Immunol. 2008; 181: 3575-85.

126. Vandivier RW, Henson PM, Douglas IS. Burying the dead: the impact of failed apoptotic cell removal (efferocytosis) on chronic inflammatory lung disease. Chest. 2006; 129: 1673-82.

127. Tabas I. Macrophage death and defective inflammation resolution in 
atherosclerosis. Nat Rev Immunol. 2010; 10: 36-46.

128. Lauber K, Bohn E, Kröber SM, Xiao Y, Blumenthal SG, Lindemann $\mathrm{RK}$, et al. Apoptotic cells induce migration of phagocytes via caspase-3-mediated release of a lipid attraction signal. Cell. 2003; 113: 717-30.

129. Elliott MR, Chekeni FB, Trampont PC, Lazarowski ER, Kadl A, Walk $\mathrm{SF}$, et al. Nucleotides released by apoptotic cells act as a find-me signal to promote phagocytic clearance. Nature. 2009; 461: 282-6.

130. Truman LA, Ford CA, Pasikowska M, Pound JD, Wilkinson SJ, Dumitriu IE, et al. CX3CL1/fractalkine is released from apoptotic lymphocytes to stimulate macrophage chemotaxis. Blood. 2008; 112: $5026-36$

131. Elliott MR, Koster KM, Murphy PS. Efferocytosis Signaling in the Regulation of Macrophage Inflammatory Responses. J Immunol. 2017; 198: 1387-94.

132. Gude DR, Alvarez SE, Paugh SW, Mitra P, Yu J, Griffiths R, et al. Apoptosis induces expression of sphingosine kinase 1 to release sphingosine-1-phosphate as a "come-and-get-me" signal. FASEB J. 2008; 22: 2629-38.

133. Weigert A, Johann AM, von Knethen A, Schmidt H, Geisslinger G, Brüne B. Apoptotic cells promote macrophage survival by releasing the antiapoptotic mediator sphingosine-1-phosphate. Blood. 2006; 108: 1635-42.

134. Peter C, Waibel M, Keppeler H, Lehmann R, Xu G, Halama A, et al. Release of lysophospholipid "find-me" signals during apoptosis requires the ATP-binding cassette transporter A1. Autoimmunity. 2012; 45: 568-73.

135. Scaffidi P, Misteli T, Bianchi ME. Release of chromatin protein HMGB1 by necrotic cells triggers inflammation. Nature. 2002; 418: 191-5.

136. Shi Y, Evans JE, Rock KL. Molecular identification of a danger signal that alerts the immune system to dying cells. Nature. 2003; 425: $516-21$.

137. Shi J, Gao W, Shao F. Pyroptosis: gasdermin-mediated programmed necrotic cell death. Trends Biochem Sci. 2017; 42: 245-54.

138. Segawa K, Nagata S. An apoptotic "rat me" signal: phosphatidylserine exposure. Trends Cell Biol. 2015; 25: 639-50.

139. Kim SJ, Gershov D, Ma X, Brot N, Elkon KB. I-PLA(2) activation during apoptosis promotes the exposure of membrane lysophosphatidylcholine leading to binding by natural immunoglobulin $\mathrm{M}$ antibodies and complement activation. J Exp Med. 2002; 196: 655-65.

140. Gardai SJ, McPhillips KA, Frasch SC, Janssen WJ, Starefeldt A, Murphy-Ullrich JE, et al. Cell-surface calreticulin initiates clearance of viable or apoptotic cells through trans-activation of LRP on the phagocyte. Cell. 2005; 123: 321-34.

141. Ogden CA, deCathelineau A, Hoffmann PR, Bratton D, Ghebrehiwet $\mathrm{B}$, Fadok VA, et al. C1q and mannose binding lectin engagement of cell surface calreticulin and CD91 initiates macropinocytosis and uptake of apoptotic cells. J Exp Med. 2001; 194: 781-95.

142. Ma Z, Thomas KS, Webb DJ, Moravec R, Salicioni AM, Mars WM, et al. Regulation of Rac1 activation by the low density lipoprotein receptor-related protein. J Cell Biol. 2002; 159: 1061-70.

143. Sévajol M, Reiser J-B, Chouquet A, Pérard J, Ayala I, Gans P, et al. The $\mathrm{C}$-terminal polyproline-containing region of ELMO contributes to an increase in the life-time of the ELMO-DOCK complex. Biochimie. 2012; 94: 823-8.

144. Waterborg CEJ, Beermann S, Broeren MGA, Bennink MB, Koenders MI, van Lent PLEM, et al. Protective role of the MER tyrosine kinase via efferocytosis in rheumatoid arthritis models. Front Immunol. 2018; 9:742. doi: 10.3389/fimmu.2018.00742.

145. Neefjes J, Jongsma MLM, Paul P, Bakke O. Towards a systems understanding of MHC class I and MHC class II antigen presentation. Nat Rev Immunol. 2011; 11: 823-36.

146. Martin CJ, Peters KN, Behar SM. Macrophages clean up: efferocytosis and microbial control. Curr Opin Microbiol. 2014; 17: 17-23.

147. Savill J, Fadok V. Corpse clearance defines the meaning of cell death. Nature. 2000; 407: 784-8.

148. Blander JM, Torchinsky MB, Campisi L. Revisiting the old link between infection and autoimmune disease with commensals and $\mathrm{T}$ helper 17 cells. Immunol Res. 2012; 54: 50-68.

149. Cai B, Thorp EB, Doran AC, Subramanian M, Sansbury BE, Lin CS, et al. MerTK cleavage limits proresolving mediator biosynthesis and exacerbates tissue inflammation. Proc Natl Acad Sci USA. 2016; 113: 6526-31

150. Serhan CN. Pro-resolving lipid mediators are leads for resolution physiology. Nature. 2014; 510: 92-101.

151. Spite M, Norling LV, Summers L, Yang R, Cooper D, Petasis NA, et al. Resolvin D2 is a potent regulator of leukocytes and controls microbial sepsis. Nature. 2009; 461: 1287-91.

152. Chiang N, Fredman G, Bäckhed F, Oh SF, Vickery T, Schmidt BA, et al. Infection regulates pro-resolving mediators that lower antibiotic requirements. Nature. 2012; 484: 524-8.

153. Godson C, Mitchell S, Harvey K, Petasis NA, Hogg N, Brady HR. Cutting edge: lipoxins rapidly stimulate nonphlogistic phagocytosis of apoptotic neutrophils by monocyte-derived macrophages. J Immunol. 2000; 164: 1663-7.

154. Schwab U, Törrönen A, Meririnne E, Saarinen M, Alfthan G, Aro A, et al. Orally administered betaine has an acute and dose-dependent effect on serum betaine and plasma homocysteine concentrations in healthy humans. J Nutr. 2006; 136: 34-8.

155. Tabas I, Bornfeldt KE. Macrophage phenotype and function in different stages of atherosclerosis. Circ Res. 2016; 118: 653-67.

156. Fredman G, Hellmann J, Proto JD, Kuriakose G, Colas RA, Dorweiler $\mathrm{B}$, et al. An imbalance between specialized pro-resolving lipid mediators and pro-inflammatory leukotrienes promotes instability of atherosclerotic plaques. Nat Commun. 2016; 7: 12859. doi: $10.1038 /$ ncomms12859.

157. Lin J, Li H, Yang M, Ren J, Huang Z, Han F, et al. A role of RIP3mediated macrophage necrosis in atherosclerosis development. Cell Rep. 2013; 3: 200-10.

158. Meng L, Jin W, Wang X. RIP3-mediated necrotic cell death accelerates systematic inflammation and mortality. Proc Natl Acad Sci USA. 2015; 112: 11007-12.

159. Karunakaran D, Geoffrion M, Wei L, Gan W, Richards L, Shangari $\mathrm{P}$, et al. Targeting macrophage necroptosis for therapeutic and diagnostic interventions in atherosclerosis. Sci Adv. 2016; 2: e1600224. doi: 10.1126/sciadv.1600224.

160. Enyedi B, Jelcic M, Niethammer P. The cell nucleus serves as a mechanotransducer of tissue damage-induced inflammation. Cell. 2016; 165: 1160-70.

161. Krysko DV, Denecker G, Festjens N, Gabriels S, Parthoens E, D'Herde $\mathrm{K}$, et al. Macrophages use different internalization mechanisms to clear apoptotic and necrotic cells. Cell Death Differ 2006; 13: 2011-22.

162. Schrijvers DM, De Meyer GRY, Kockx MM, Herman AG, Martinet W. Phagocytosis of apoptotic cells by macrophages is impaired in atherosclerosis. Arterioscler Thromb Vasc Biol. 2005; 25: 1256-61.

163. Vucic E, Calcagno C, Dickson SD, Rudd JHF, Hayashi K, Bucerius $\mathrm{J}$, et al. Regression of inflammation in atherosclerosis by the LXR agonist R211945. JACC Cardiovasc Imaging. 2012; 5: 819-28.

164. Li BZ, Zhang HY, Pan HF, Ye DQ. Identification of MFG-E8 as a novel therapeutic target for diseases. Expert Opin Ther Targets. 2013; 17: 1275-85. 